\title{
Heavy metal concentrations and size effects in the mesopelagic decapod crustacean Systellaspis debilis
}

\author{
S. L. White \& P. S. Rainbow \\ School of Biological Sciences, Queen Mary College, University of London, Mile End Road, London E1 4NS, England
}

\begin{abstract}
Specimens of the oceanic decapod crustacean Systellaspis debilis from the NE Atlantic were analysed for whole body concentrations of $\mathrm{Cu}, \mathrm{Zn}, \mathrm{Fe}, \mathrm{Mn}$ and $\mathrm{Cd}$. Concentrations of $\mathrm{Zn}, \mathrm{Fe}, \mathrm{Mn}$ and $\mathrm{Cd}$ decreased with increasing $\mathrm{dry}$ weight; $\mathrm{Cu}$ concentrations increased. Theoretical metabolic requirements for $\mathrm{Zn}, \mathrm{Mn}$ and Fe in a decapod crustacean were estimated and are closely matched by the concentrations measured in $S$. debilis. The low copper concentrations may be explained by a low body content of haemocyanin.
\end{abstract}

\section{INTRODUCTION}

Trace metals are generally more concentrated in marine organisms than in the surrounding seawater and concentration factors may reach many thousand fold. Marine organisms are obligate accumulators of metabolically essential metals like copper, zinc and iron but also accumulate non-essential metals such as cadmium and lead, possibly via transport pathways common to essential metals. The potential of marine organisms, especially invertebrates, to concentrate trace metals has prompted their use as monitors of metal concentrations in estuarine and coastal environments (Phillips 1976a, b, 1977, 1980, Bryan \& Hummerstone 1978, Bryan et al. 1980), and a large volume of data has been accumulated (e.g. Eisler 1981).

Oceanic waters away from anthropogenic influence may be expected to have 'background' concentrations of trace metals and indeed measurements have shown concentrations to be considerably (more than 10 times) lower than in coastal waters (Bruland 1983, Jones \& Jeffries 1983). Metal concentrations in oceanic invertebrates might therefore be expected to be considerably lower than those in coastal species. There are however relatively few data on trace metal concentrations in oceanic invertebrates which can be used to make such comparisons. Leatherland et al. (1973) reported concentrations of several metals in a number of pelagic organisms from the NE Atlantic. Of particular note in their study were the high concentrations of cadmium ( 3 to $13 \mu \mathrm{g} \mathrm{Cd} \mathrm{g}^{-1}$ dry wt) in 3 species of decapod crustaceans. These cadmium concentrations are comparable to those found in decapod crustaceans from cadmium-polluted coastal environments, such as the Bristol Channel, Britain (Peden et al. 1973, Hardisty et al. 1974). More recently Ridout et al. (1985) reported concentrations of $\mathrm{Mn}, \mathrm{Fe}, \mathrm{Cu}, \mathrm{Zn}$ and $\mathrm{Cd}$ in the mesopelagic decapod Systellaspis debilis from several sites in the E Atlantic, supporting data presented by Leatherland et al. (1973).

The effect of individual animal size on metal concentrations has been widely recognised, particularly in monitoring studies using indicator species (e.g. Boyden 1977, Phillips 1977, Bryan et al. 1980). While knowledge of size-metal concentration relationships is clearly important for such studies, they may have a wider significance by being indicative of the biology and physiology with regard to metals of the organisms studied.

In order to minimize the effect of any size-metal concentration relationships, Ridout et al. (1985) presented data for Systellaspis debilis of only a limited size range. The present study extends this work by examining the effect of size on the concentrations of $\mathrm{Cu}, \mathrm{Zn}, \mathrm{Fe}, \mathrm{Mn}$ and $\mathrm{Cd}$ in $\mathrm{S}$. debilis. The measured metal concentrations are also examined in terms of estimated metabolic requirements.

\section{MATERLALS AND METHODS}

Sampling. Systellaspis debilis (Milne Edwards) were collected on 9 Jun 1984 (0530 to 0730 h) at $35^{\circ} 48^{\prime} \mathrm{N}$, 
$18^{\circ} 51^{\prime} \mathrm{W}$, in a rectangular mid-water trawl $(4.5 \mathrm{~mm}$ mesh) with a closing cod-end at a sampling depth of 590 to $700 \mathrm{~m}$ during RRS Discovery Cruise No. 148. Specimens were sexed prior to being transferred to individual polythene bags and deep frozen $\left(-20^{\circ} \mathrm{C}\right)$ for shipment to the U.K.

Sample preparation and analysis. After thawing, specimens were rinsed in double-distilled water to remove particulate matter, then dried in acid-washed test-tubes at $60^{\circ} \mathrm{C}$ to constant weight. Dried samples were digested using concentrated nitric acid (Aristar grade, $\mathrm{BDH}$ Ltd; $\sim 3 \mathrm{ml} \mathrm{g}^{-1}$ dry material) at $100^{\circ} \mathrm{C}$. Digested samples were made up to volume with double-distilled water and analysed for copper $(\mathrm{Cu})$, zinc $(\mathrm{Zn})$, iron $(\mathrm{Fe})$, manganese $(\mathrm{Mn})$ and cadmium $(\mathrm{Cd})$ using a Varian AA375 atomic absorption spectrophotometer with flame atomization and deuterium arc background correction. All body metal concentrations are quoted in $\mu \mathrm{g} \mathrm{g}^{-1}$ dry weight.

Data were fitted to linear regression equations using analysis of variance according to Sokal \& Rohlf (1969).

\section{RESULTS}

Fig. 1 to 5 show linear plots of concentration against dry weight for the 5 metals studied. As there were no apparent differences in metal concentration-size relations between juveniles, males and females, the regression equations are based on all individuals. Tables 1 \& 2 summarize the statistical data.

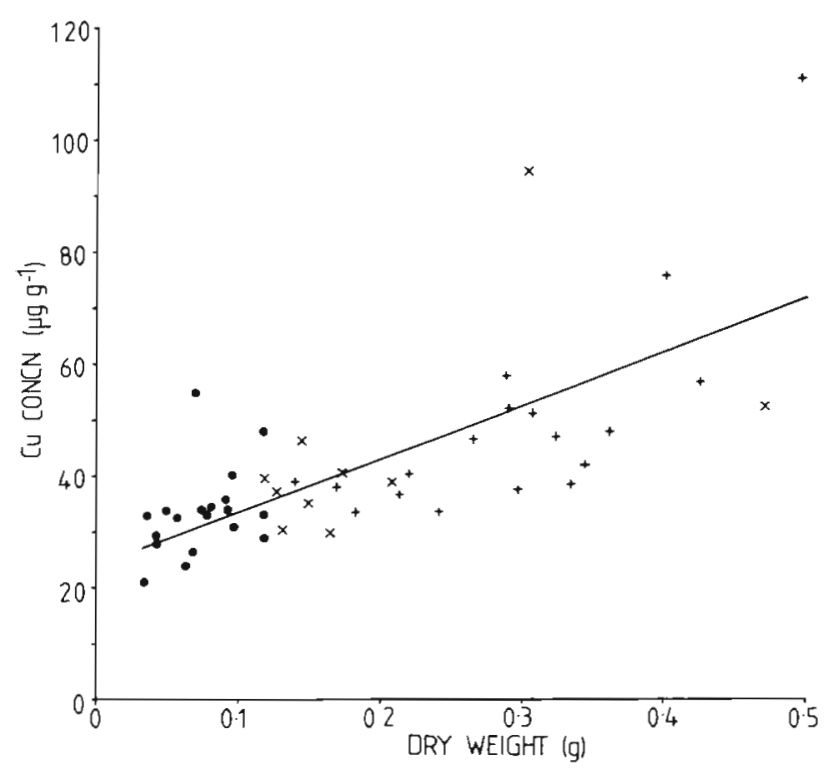

Fig. 1. Systellaspis debilis. Relation between copper concentration $(\mathrm{Y})$ and individual dry weight $(\mathrm{X})$. Fitted curve is $Y=95.47 X+24.27$ See Table 2 for regression statistics. (•) Juveniles; $(x)$ males; ( + ) females

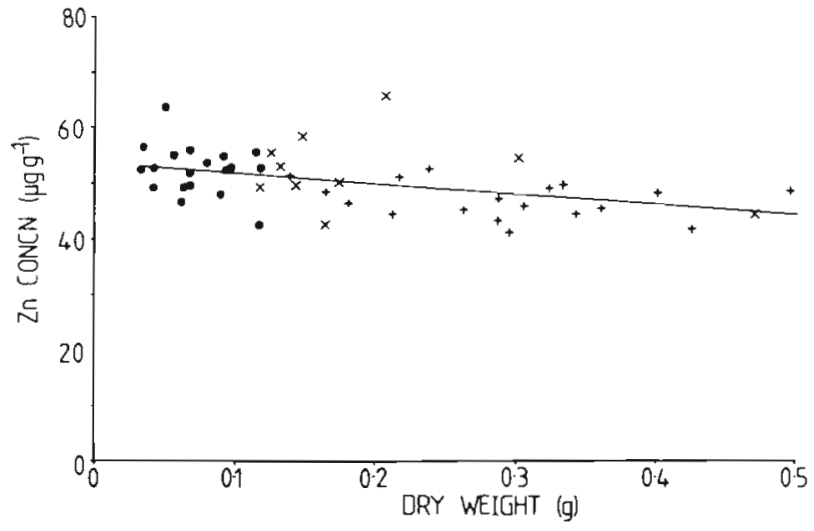

Fig. 2. Systellaspis debilis. Relation between zinc concentration $(\mathrm{Y})$ and individual dry weight $(\mathrm{X})$. Fitted curve is $\mathrm{Y}=$ $53.63-19.22 \mathrm{X}$. Other details as for Fig. 1

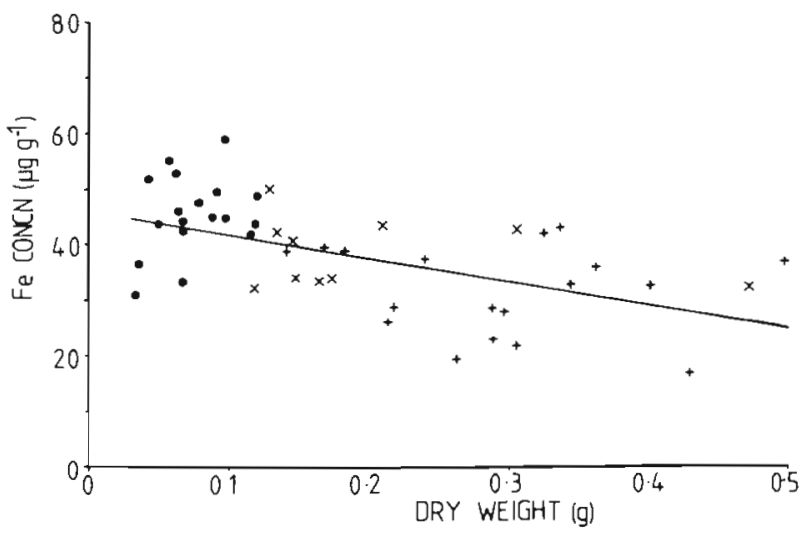

Fig. 3. Systellaspis debilis. Relation between iron concentration $(\mathrm{Y})$ and individual dry weight $(\mathrm{X})$. Fitted curve is $\mathrm{Y}=$ $46.07-41.14 X$. Other details as for Fig. 1

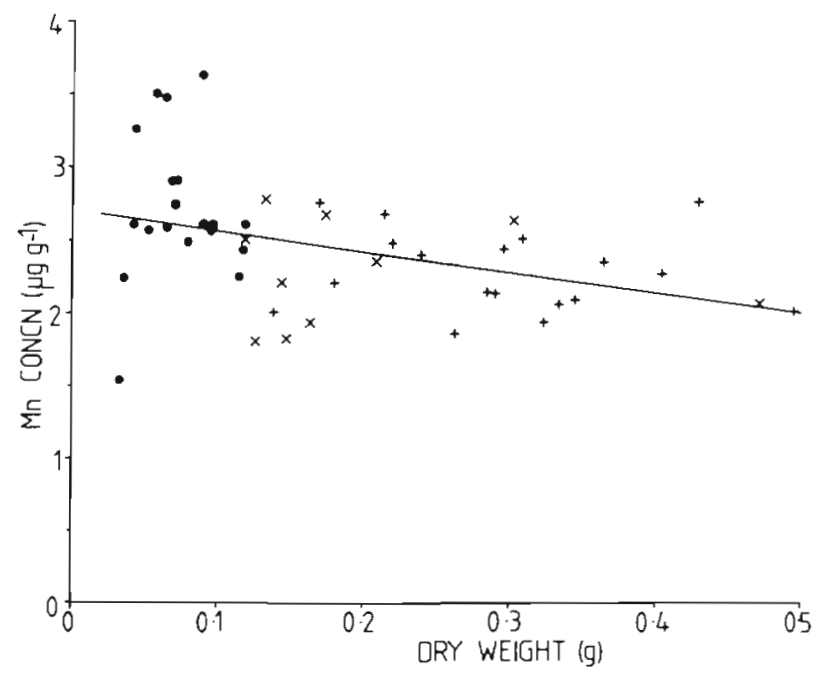

Fig. 4. Systellaspis debilis. Relation between manganese concentration $(\mathrm{Y})$ and individual dry weight $(\mathrm{X})$. Fitted curve is $\mathrm{Y}=2.71-1.347 \mathrm{X}$. Other details as for Fig. 1 
Table 1. Systellaspis debilis. Dry weight $(\mathrm{g})$ and metal concentration $\left(\mu \mathrm{g} \mathrm{g}^{-1}\right)$ in decapods collected in a single mid-water trawl in the NE Atlantic Ocean

\begin{tabular}{lccccccc|}
\hline & & & \multicolumn{3}{c|}{ Metal concentration } \\
& Dry weight & $\mathrm{Cu}$ & $\mathrm{Zn}$ & $\mathrm{Mn}$ & $\mathrm{Fe}$ & $\mathrm{Cd}$ \\
\hline Mean & 0.1850 & 41.9 & 50.1 & 2.46 & 38.1 & 12.8 \\
$\mathrm{SD}$ & 0.1256 & 16.8 & 5.2 & 0.45 & 9.4 & 2.9 \\
Range & $0.0355-0.4972$ & $20.9-112$ & $40.8-65.4$ & $1.53-3.66$ & $16.4-58.5$ & $5.7-17.8$ \\
$\mathrm{n}$ & 47 & 47 & 47 & 47 & 46 & 47 \\
\end{tabular}

Table 2. Systellaspis debilis. Regression data for linear rela-

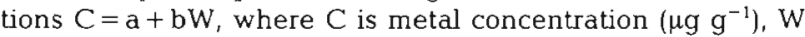
dry weight $(\mathrm{g})$ and $\mathrm{a}$ (the intercept) and $\mathrm{b}$ (the regression coefficient) are constants. Fs: F statistic; p: probability that $\mathrm{b}=0 ; \mathrm{r}^{2}$ : square of the correlation coefficient

\begin{tabular}{|crrrrrr|}
\hline Metal & a & \multicolumn{1}{c}{$\mathrm{b}$} & \multicolumn{1}{c}{ Fs } & $\mathrm{p}$ & $\mathrm{r}^{2}$ \\
\hline $\mathrm{Cu}$ & 24.268 & 95.472 & 46.64 & $<0.001$ & 0.509 \\
$\mathrm{Zn}$ & 53.627 & -19.218 & 12.41 & $<0.001$ & 0.216 \\
$\mathrm{Fe}$ & 46.073 & -42.452 & 20.88 & $<0.001$ & 0.322 \\
$\mathrm{Mn}$ & 2.714 & -1.347 & 7.45 & $<0.01$ & 0.142 \\
$\mathrm{Cd}$ & 14.794 & -10.742 & 12.67 & $<0.001$ & 0.220 \\
\hline
\end{tabular}

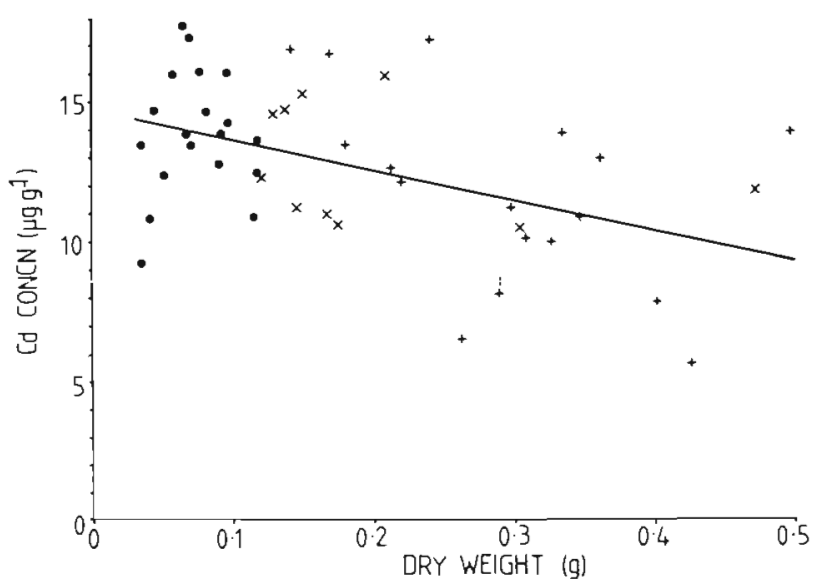

Fig. 5. Systellaspis debilis. Relation between cadmium concentration ( $\mathrm{Y}$ ) and individual dry weight (X). Fitted curve is $\mathrm{Y}=14.79-10.74 \mathrm{X}$. Other details as for Fig. 1
For all the metals analysed, the concentration varied significantly $(p<0.05$ ) with the dry weight of the shrimps, decreasing for $\mathrm{Zn}, \mathrm{Fe}, \mathrm{Mn}$ and $\mathrm{Cd}$, increasing for $\mathrm{Cu}$.

White \& Rainbow (1985) have examined the metabolic requirements of crustaceans for zinc and copper by estimating the amounts required for enzymatic and non-enzymatic uses. The calculations were largely based on the proportion of enzymes known to be associated with copper or zinc and on the concentration, and metal content, of the respiratory pigment haemocyanin typically found in coastal decapod crustaceans (White \& Rainbow 1985). Such calculations can be extended to estimate the metabolic requirements of manganese and iron in crustaceans (Table 3). There is no known metabolic requirement for cadmium. Table 4 compares estimated metal requirements with measured concentrations in Systellaspis debilis.

\section{DISCUSSION}

The concentration of copper in Systellaspis debilis increased with increasing size from 20.9 to $112 \mu \mathrm{g} \mathrm{Cu}$ $\mathrm{g}^{-1}$. The concentration in the smallest individuals is therefore of the order of the estimated enzymatic requirement alone. This suggested that small $S$. debilis might have little or no haemocyanin. Preliminary measurements on whole specimens have shown that small $S$. debilis (ca $0.1 \mathrm{~g}$ ) have less than half the haemo-

Table 3. Estimates of enzymatic, haemocyanin and total requirements $\left(\mu \mathrm{g} \mathrm{g}^{-1}\right.$ ) for $\mathrm{Cu}, \mathrm{Zn}, \mathrm{Fe}$ and $\mathrm{Mn}$ in crustaceans (after White \& Rainbow 1985)

\begin{tabular}{|c|c|c|c|c|}
\hline & $\mathrm{Cn}$ & $\mathrm{Zn}$ & $\mathrm{Fe}$ & $\mathrm{Mn}$ \\
\hline No. of metal-associated enzymes ${ }^{d}$ & 30 & 80 & 70 & 12 \\
\hline Percentage of total enzyme no. $(2137)^{b}$ & 1.40 & 3.74 & 3.28 & 0.56 \\
\hline $\begin{array}{l}\text { Average no. of metal atoms per molecule of metal- } \\
\text { associated enzyme }\end{array}$ & 2.95 & 1.41 & 1.5 & 1.25 \\
\hline Estimated enzymatic requirement & 26.3 & 34.5 & 27.4 & 3.9 \\
\hline Haemocyanin metal requirement ${ }^{c}$ & 57.4 & 36.3 & - & - \\
\hline Total metabolic requirement & 83.7 & 70.8 & 27.4 & 3.9 \\
\hline
\end{tabular}


Table 4. Systellaspis debilis. Comparison of estimated metabolic metal requirements with measured concentrations $\left(\mu \mathrm{g} \mathrm{g}^{-1}\right.$ )

\begin{tabular}{|c|c|c|c|c|}
\hline & $\mathrm{Cu}$ & $\mathrm{Zn}$ & $\mathrm{Fe}$ & Mn \\
\hline Estimated enzymatic requirement & 26.3 & 34.5 & 27.4 & 3.9 \\
\hline Estimated haemocyanin requirement & $\underline{57.4}$ & $\underline{36.3}$ & 0 & $\underline{0}$ \\
\hline Total requirement & 83.7 & 70.8 & 27.4 & 3.9 \\
\hline Measured metal concentration (range) & $20.9-111.6$ & $40.8-65.4$ & $16.4-58.5$ & $1.5-3.7$ \\
\hline
\end{tabular}

cyanin (per unit weight) of that in the coastal decapod species Palaemon elegans (unpubl. obs.), which typically has a copper concentration of $110 \mu \mathrm{g} \mathrm{Cu} \mathrm{g}^{-1}$ (White \& Rainbow 1982). In larger S. debilis however the haemocyanin concentration approaches that in $P$. elegans and it is probable that this explains the corresponding increase in copper concentration. Juvenile $S$. debilis undergo a less distinct daily vertical migration than adults (Roe 1984, pers. comm.). This may be related to the low haemocyanin content of young decapods and might indicate that low bioavailability of copper in the mesopelagic environment is a limiting factor to the activity of these animals, at least until sufficient copper has been accumulated to allow increased haemocyanin levels.

The concentration of zinc in Systellaspis debilis decreased slightly with increasing size ranging from 65.4 to $40.8 \mu \mathrm{g} \mathrm{Zn} \mathrm{g}^{-1}$, in good agreement with the figure of $50 \mu \mathrm{g} \mathrm{Zn} \mathrm{g}{ }^{-1}$ reported by Leatherland et al. (1973). The estimated total metabolic requirement for zinc is slightly above the measured concentrations in $S$. debilis but this may be explained by the relatively low haemocyanin concentrations, the zinc possibly being involved in stabilisation of the quaternary structure of the haemocyanin molecule (Martin et al. 1977, see White \& Rainbow 1985). By comparison coastal natantian decapod species have body zinc concentrations that are regulated at 80 to $100 \mu \mathrm{g} \mathrm{Zn} \mathrm{g}^{-1}$ over a wide range of external zinc concentrations (White \& Rainbow 1982, Devineau \& Amiard-Triquet 1985).

The concentration of iron in Systellaspis debilis decreased with increasing size though most samples were close to the estimated metabolic requirement of $27 \mu \mathrm{g} \mathrm{Fe} \mathrm{g}^{-1}$. The iron concentrations in $S$. debilis are lower than the few reported measurements on crustaceans (see Eisler 1981) although White (1982) found concentrations of 15 to $55 \mu \mathrm{g} \mathrm{Fe} \mathrm{g}^{-1}$ in Palaemon elegans.

The concentrations of manganese in Systellaspis debilis again decreased with increasing size but the concentrations were very low and indeed were slightly lower than the calculated metabolic requirement for the metal, $3.9 \mu \mathrm{g} \mathrm{Mn} \mathrm{g}^{-1}$. There are few reported concentrations of manganese in decapod crustaceans; Bryan \& Ward (1965) reported $128 \mu \mathrm{g} \mathrm{g}^{-1}$ in Homarus vulgaris though most (98\%) of the manganese was associated with the heavily calcified exoskeleton. Concentrations in less calcified forms are lower; Knauer (1970) reported $6.1 \mu \mathrm{g} \mathrm{Mn} \mathrm{g}^{-1}$ in Penaeus spp. and White (1982) found $7.9 \mu \mathrm{g} \mathrm{g}^{-1}$ in Palaemon elegans. While these concentrations are somewhat higher than found in $S$. debilis, concentrations in euphausids, 2.2 to $4.5 \mathrm{\mu g} \mathrm{Mn} \mathrm{g}^{-1}$ (Martin \& Knauer 1973, Fowler 1977), are in good agreement and closely match the estimated metabolic requirements.

As discussed by Ridout et al. (1985) the cadmium concentrations for Systellaspis debilis agree well with the figure of $13 \mu \mathrm{g} \mathrm{g}^{-1}$ reported by Leatherland et al. (1973) but are considerably higher than concentrations typical of coastal decapods, 1 to $2 \mu \mathrm{g} \mathrm{g} \mathrm{g}^{-1}$ (White \& Rainbow 1982). Given the low concentrations of cadmium in oceanic waters it is likely that the diet is the major source of cadmium (Ridout et al. 1985).

The concentrations of all 5 metals showed significant, though often small, variations with individual dry weight but approximate to the estimated metabolic requirements. With the exception of copper it is possible that the decrease in concentration with increasing dry weight is a surface area effect relating to a proportion of the total metal content associated with the external surface of the decapods and therefore not under metabolic influence. While such an effect would tend to give a curvilinear relation the variability in these data may mask such trends. A variety of curvilinear models fitted to these data showed little if any improvement over the linear model and have therefore not been considered here.

Acknowledgements. SLW was funded by NERC grant GR 3/ 5256 awarded to PSR, and acknowledges the financial support of Professor E. A. Bevan (QMC) to cover travel expenses. Grateful thanks are due to Howard S. J. Roe and Paul S Ridout (Institute of Oceanographic Sciences, Wormley) for their interest and assistance, and to the officers and the crew of RRS Discovery on Cruise 148 .

\section{LITERATURE CITED}

Bowen, H. J. M. (1979). Environmental chemistry of the elements. Academic Press, London 
Boyden, C. R. (1977). Effect of size upon metal content of shellfish. J. mar. biol. Ass. U.K. 57: 675-714

Bruland, K. W. (1983). Trace elements in seawater. In: Riley, J. P., Chester, R. (ed.) Chemical Oceanography. Academic Press, London, p. 257-220

Bryan, G. W., Hummerstone, L. G. (1978). Heavy metals in the burrowing bivalve Scrobicularia plana from contaminated and uncontaminated estuaries. J. mar. biol. Ass. U.K. 58: $401-419$

Bryan, G. W., Langston, W. J., Hurnmerstone, L. G. (1980). The use of biological indicators of heavy metal contamination in estuaries. Mar biol. Ass. U.K., Plymouth

Bryan, G. W., Ward, E. (1965). The absorption and loss of radioactive and non-radioactive manganese by the lobster Homarus vulgaris. J. mar. biol. Ass. U.K. 45: 65-95

Devineau, J., Amiard-Triquet, C. (1985). Patterns of bioaccumulation of an essential trace element (zinc) and a pollutant metal (cadmium) in the larvae of the prawn Palaemon serratus. Mar. Biol. 86: 139-143

Dixon, M., Webb, E. C. (1979). Enzymes. 3rd edn. Longman, London

Eisler, R. (1981). Crustacea. Trace metal concentrations in marine organisms. Pergamon Press, New York, p. 326-401

Fowler, S. W. (1977). Trace elements in zooplankton particulate products. Nature, Lond. 269: 51-53

Hardisty, M. W., Huggins, R. J, Katar, S., Sainsbury, M. (1974). Ecological implications of heavy metals in fish from the Severn Estuary. Mar. Pollut. Bull., U.S. 5: 12-15

Jones, P. G. W., Jeffries, P. F. (1983). The distribution of selected trace metals in United Kingdom shelf waters and the North Atlantic. Can. J. Fish. aquat. Sci. 40 (Suppl. 2): $111-123$

Knauer, G. A. (1970). The determination of magnesium, manganese, iron, copper, and zinc in marine shrimp. Analyst 93: $476-480$

Leatherland, T. M., Burton, J. D., Culkin, F., McCartney, M. J., Morris, R. J. (1973). Concentrations of some trace

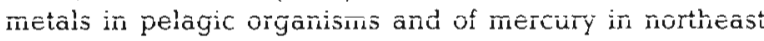
Atlantic Ocean water. Deep Sea Res. 20: 679-685
Martin, J.-L. M., Knauer, G. A. (1973). The elemental composition of plankton. Geochim. cosmochim. Acta 37: $1639-1653$

Martin, J.-L. M., van Wormhoudt, A., Ceccaldi, H. J. (1977), Zinc-haemocyanin binding in the hemolymph of Carcinus maenas (Crustacea, Decapoda). Comp. Biochem. Physiol. 58A: 193-195

Peden, J. D., Crothers, J. H., Waterfall, C. E., Beasley, J. (1973). Heavy metals in Somerset marine organisms. Mar. Pollut. Bull., U.S. 4: 7-10

Phillips, D. J. H. (1976a). The common mussel Mytilus edulis as an indicator of pollution by zinc, cadmium, lead and copper. I. Effects of environmental variables on uptake of metals. Mar. Biol. 38: 59-69

Phillips, D. J. H. (1976b). The common mussel Mytilus edulis as an indicator of pollution by zinc, cadmium, lead and copper. II. Relationships of metals in the mussel to those discharged by industry. Mar. Biol. 38: 71-80

Phillips, D. J. H. (1977). The use of biological indicator organisms to monitor trace metal pollution in marine and estuarine environments - a review. Environ. Pollut. 13: 281-317

Phillips, D. J. H. (1980). Quantitative aquatic biological indicators. Applied Science Publishers, Barking

Ridout, P. S., Willcocks, A. D., Morris, R. J., White, S. L., Rainbow, P. S. (1985). Concentrations of $\mathrm{Mn}, \mathrm{Fe}, \mathrm{Cu}, \mathrm{Zn}$ and $\mathrm{Cd}$ in the mesopelagic decapod Systellaspis debilis from the East Atlantic Ocean. Mar. Biol. 87: 285-288

Sokal, R. R., Rohlf, F. J. (1969). Biometry. The principles and practice of statistics in biological research. W. H. Freeman \& Co., San Francisco

White, S. L. (1982). Aspects of the biology of zinc, cadmium and copper in a decapod crustacean, Palaemon elegans Ph. D. thesis University of London

White, S. L., Rainbow, P. S. (1982). Regulation and accumulation of copper, zinc and cadmium by the shrimp Palaemon elegans. Mar Ecol. Prog. Ser. 8: 95-101

White, S. L., Räintôn, P. S. (1085). On the metabolic requircments for copper and zinc in molluscs and crustaceans Mar. environ. Res. 16: 215-229 